\title{
Canine distemper, a re-emerging morbillivirus with complex neuropathogenic mechanisms
}

\author{
Christian Griot ${ }^{1,2} *$, Marc Vandevelde ${ }^{2}$, Martina Schobesberger ${ }^{2}$ and \\ Andreas Zurbriggen ${ }^{2}$ \\ ${ }^{1}$ Institute of Virology and Immunoprophylaxis, Swiss Federal Veterinary Office, 3147 \\ Mittelhäusern and ${ }^{2}$ Institute of Animal Neurology, University of Bern, 3012 Bern, \\ Switzerland
}

\section{Received 29 October 2002; Accepted 9 December 2002}

\begin{abstract}
Paramyxoviruses are responsible for a wide variety of diseases both in humans and in animals. Common to many paramyxoviruses is the fact that they can cause neurological symptoms in their final host. Newly discovered paramyxoviruses, such as the Hendra and Nipah viruses, show the same pattern of pathogenesis as that of the paramyxoviruses already known. Canine distemper virus (CDV) is a well-studied member of the genus Morbillivirus. Study of the neuropathogenesis of CDV might give insight into disease mechanisms and suggest approaches for the prevention of other recently discovered paramyxovirus infections.
\end{abstract}

Keywords: canine distemper, morbillivirus, dogs, henipah, neuropathology

\section{Introduction}

Members of the family Paramyxoviridae are responsible for a variety of important diseases affecting livestock (e.g. rinderpest, Newcastle disease), pet animals (e.g. canine distemper) and man (e.g. measles) (Table 1). The most significant economic losses in livestock are caused by rinderpest virus and Newcastle disease virus. Canine distemper is the most important viral disease in dogs, with high morbidity and mortality in unvaccinated populations worldwide. In humans, measles continues to be a significant cause of infant mortality in developing countries. Also, in industrialized countries, outbreaks of importance are occasionally observed in children, probably as a result of inadequate vaccination programs.

During the past two decades, several novel paramyxoviruses have emerged (such as Hendra, Nipah and phocine distemper virus) and several previously described paramyxoviruses [such as canine distemper

*Corresponding author: Institute of Virology and Immunoprophylaxis, P.O. Box 17, Sensemattstrasse 293,

$\mathrm{CH}-3147$ Mittelhäusern, Switzerland

E-mail: Christian.Griot@ivi.admin.ch

Fax: $+41(0) 318489222$ virus (CDV)] have crossed the species barrier. Many of these newer and older members of the family Paramyxoviridae can cause neurological symptoms because of invasion of virus and/or immune cells into the central nervous system (CNS). The detailed studies of the neuropathogenesis of CDV that have been carried out might therefore give some insight into similar disease patterns among the emerging paramyxoviruses. This review provides a brief summary of our knowledge of important emerging paramyxoviruses and of the pathogenesis of CDV in dogs.

\section{Henipah, a new genus in the family Paramyxoviridae}

Recently, a new group of paramyxoviruses closely related but distinct from the genus Morbillivirus has been discovered. These viruses, which were first identified in Australia (Hendra) and Malaysia (Nipah), cause subclinical infection in fruit bats, and have caused mortality in horses, pigs and humans. Both viruses were initially classified as Morbillivirus-like, but will now be assigned to a new genus, Henipah, within the paramyxovirus family (Mayo, 2002) (Tables 1 and 2). 
Table 1. Examples of the family Paramyxoviridae

\begin{tabular}{|c|c|c|c|c|}
\hline Genus & Virus & Host & $\begin{array}{l}\text { Re-emerging and/or } \\
\text { emerging }\end{array}$ & Vaccination $^{2}$ \\
\hline \multirow[t]{2}{*}{ Respirovirus } & Parainfluenza 1-3 & Mammals & No & Yes \\
\hline & Paramyxovirus & Pig & Yes & Yes \\
\hline \multirow[t]{6}{*}{ Morbillivirus } & Measles & Human & Yes & $\mathrm{Yes}^{3}$ \\
\hline & Canine distemper & $\begin{array}{l}\text { Carnivores, } \\
\text { seal }\end{array}$ & Yes & Yes \\
\hline & Phocid distemper ${ }^{1}$ & Seal & Yes & No \\
\hline & Dolphin morbillivirus & Dolphin & Yes & No \\
\hline & Rinderpest & Cattle & No & Yes \\
\hline & Peste des petites ruminantes & Sheep, goat & No & Yes \\
\hline \multirow[t]{2}{*}{ Rubellavirus } & Mumps & Human & No & Yes \\
\hline & Newcastle disease & Fowl & No & Yes \\
\hline Pneumovirus & $\begin{array}{l}\text { Bovine respiratory } \\
\text { syncytial }\end{array}$ & Cattle & No & Yes \\
\hline Metapneumovirus & Turkey rhinotracheitis & Turkey & Yes & Yes \\
\hline \multirow[t]{2}{*}{ Henipah } & Hendra & Horse, human ${ }^{5}$ & Yes & No \\
\hline & Nipah & Pig, human 5 & Yes & $\mathrm{No}^{4}$ \\
\hline Unassigned & Menangle & Pig, human 5 & Yes & No \\
\hline
\end{tabular}

${ }^{1}$ Also called phocine distemper virus; ${ }^{2}$ common vaccination practice; ${ }^{3}$ vaccination coverage in certain areas, population groups rather poor; ${ }^{4}$ experimental vaccine (T. McKenna, personal communication), ${ }^{5}$ fruit bat reservoir, modified after Wang and Eaton, 2001.

In September 1994, a sudden outbreak due to a previously unknown agent caused the deaths of 13 horses and a human due to a hyperacute respiratory disease with mild neurological symptoms. Subsequently, another outbreak was recorded in a single horse in Cairns (Australia) in 1999 (for review see Barclay and Paton, 2000; Hooper and Williamson, 2000; Mackenzie et al., 2001; Wang and Eaton, 2001). The virus is not highly contagious since transmission from horses to other horses and to humans occurs only after very close contact with an infected individual. Serological studies have shown that other species, such as dogs, cats and livestock species, have not been infected by the virus so far. The causative agent was initially called 'equine morbillivirus', but subsequent genetic analyses showed that its most appropriate classification is as the prototype member of a new genus within the family Paramyxoviridae (Murray et al., 1995, 1998; Rogers et al., 1996; O'Sullivan et al., 1997; Chua et al., 2000; Harcourt et al., 2000; Wang et al., 2000; Mayo 2002).

Although it had been presumed that Nipah virus had caused a low level of mortality in pigs in Malaysia since 1996, the virus remained unknown until September 1998, when a major outbreak in humans and pigs resulted in over 265 infected humans, 105 of whom died of encephalitis, and the slaughter of over 1.2 million pigs since then. In contrast to Hendra virus, Nipah virus was found to be contagious and the authorities were forced to choose culling as the only option to control the spread of the virus (Chua et al., 1999, 2000, 2002; Mackenzie et al., 2001). Unlike the respiratory disease caused by Hendra virus in horses, Nipah virus infection in pigs led to subclinical infection with mild respiratory symptoms and occasional CNS involvement (Table 2). In humans, Nipah virus infected the CNS and caused encephalitis and death (Lam et al., 2002). In contrast to Hendra virus, Nipah virus appears to be able to infect other animals, such as dogs, rats, and even a variety of avian species. The introduction of intensive pig farming in areas where the fruit bat is present as a vector was probably the direct cause of the appearance of Nipah virus in pigs. Recent studies even suggest that Nipah virus is more widespread in Southeast Asia than previously documented (Olson et al., 2002).

The detailed molecular characteristics of both Hendra and Nipah virus have been published (for review see Wang and Eaton, 2001). In summary, Hendra and Nipah viruses resemble respiroviruses and morbilliviruses more closely than rubellaviruses. However, they have features that make them unique and distinct and therefore justify classification as a new genus within the family Paramyxoviridae, Henipah (Wang and Eaton, 2001). Since Hendra and Nipah are zoonotic viruses, it needs to be pointed out that work with these viruses must be carried out strictly in approved biosafety level 4 laboratories.

In addition, there are several other viruses not yet assigned to the paramyxovirus family. Menangle virus was isolated in 1997 from piglets in Australia, and two humans seroconverted after having close contact with the infected animals. It is likely, with increasing disease awareness and surveillance, that new viruses of the family Paramyxoviridae will be found in other species. 


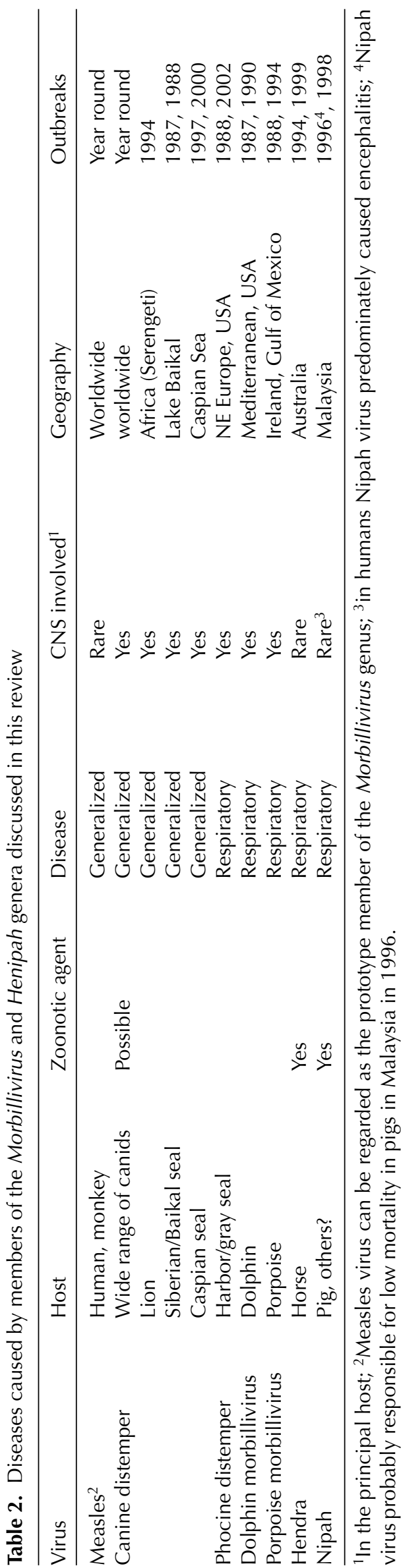

\section{Morbilliviruses of carnivores and aquatic mammals}

CDV is the only member of the genus Morbillivirus, which in the past has been associated with disease in a wide range of carnivores. In the past two decades, however, CDV has crossed the species barrier on several occasions and has caused significant problems after its introduction into a new species. Many aspects of CDV, including its molecular biology, diagnosis, host range and epidemiology, have been reviewed in earlier publications (Vandevelde and Zurbriggen, 1995; Stettler et al., 1997; Barrett, 1999; Cherpillod et al., 1999; Leisewitz et al., 2001; Deem et al., 2000) and will not be discussed here.

Although live attenuated vaccines have been used successfully for many years to control morbillivirus diseases, canine distemper continues to be a problem, outbreaks occurring in domestic dogs and farmed mink populations. The current vaccines on the market have some severe drawbacks. It was suggested earlier that the insufficient protection provided by the vaccine strains might be the consequence of changes occurring in the vaccine virus after cell culture passages (Stettler and Zurbriggen, 1995; Bolt et al., 1997; Iwatsuki et al., 1997). Other side-effects of vaccination are (i) the potential induction of immunosuppression, (ii) CNS complications (Hartley, 1974; Cornwell et al., 1988), (iii) mortality in species other than carnivores (Bush et al., 1976; Carpenter et al., 1976; Barrett, 1999), and (iv) occasional insufficient protection (Johnson et al., 1995; Gemma et al., 1996; Ek-Kommonen et al., 1997).

Besides the known susceptible species in the order Carnivora, CDV has found many other hosts in past years, and can therefore be classified as an emerging virus in these new target species. For example, CDV was isolated from the African wild dog (van de Bildt et al., 2002), the Caspian seal (Kennedy et al., 2000) and the Baikal seal (Osterhaus et al., 1989) (Table 2). Seroprevalence to CDV has also been shown in the family Felidae, in particular the Serengeti lion (Morell, 1996; Roelke-Parker et al., 1996; Cleaveland et al., 2000) and domestic cats in Japan and Taiwan (Ikeda et al., 2001). Therefore, alternative vaccines, such as DNA vaccines, and vaccine delivery systems (ISCOMS) for CDV (and other members of the paramyxovirus family) are urgently needed.

In addition, viruses related to $\mathrm{CDV}$ have been described recently: the phocine (seal) distemper virus (PDV) and the dolphin (Cetacean) morbillivirus (DMV). PDV was first found in harbor seals in 1988, and led to a mortality of $50 \%$ of the total harbor seal population in North-Western Europe (Osterhaus et al., 1988; Osterhaus and Vedder, 1988; Appel et al., 1994; Duignan et al., 1995; Harder et al., 1995; Brown, 1997). For unknown reasons, PDV re-emerged in the seal population in several countries in Northern Europe in June 2002, and killed at least 18000 seals (Jensen et al., 2002). DMV caused mortality among striped dolphins in the 
Mediterranean Sea and the Gulf of Mexico (Table 2). This virus is distantly related to PDV and CDV (Barrett et al., 1993). The epidemiology of these outbreaks remains mostly obscure. However, factors that have been suggested to be responsible for the emergence of these viruses in aquatic populations are (i) transmission due to close contact with distemper-infected dogs and other carnivores and aquatic mammals infected with the above-mentioned viruses, and (ii) a weakened immune system as a result of environmental stress (Barrett, 1999; Osterhaus 2001; Wang and Eaton, 2001).

\section{Canine distemper in carnivores}

CDV is generally transmitted as an aerosol infection of the upper respiratory tract. The primary replication of the virus takes place in the lymphoid tissues, leading to severe, long-lasting immunosuppression (Appel, 1969; Krakowka et al., 1980; Krakowka, 1982). T cells are more affected than $\mathrm{B}$ cells and $\mathrm{CD} 4^{+}$lymphocytes are rapidly depleted for several weeks, whereas $\mathrm{CD}^{+}$cells are less affected and recover relatively rapidly. About 10 days after infection, CDV starts to spread from the sites of primary replication to various epithelial tissues and the CNS. As a result of epithelial infection, a variety of respiratory, intestinal and dermatological signs can occur. The most serious complication is infection of the CNS, leading to a variety of neurological symptoms with poor prognosis (Tipold et al., 1996). Understanding of the mechanisms by which CDV causes damage to the CNS is important in the design of new strategies for therapy.

\section{Neuropathology of nervous canine distemper}

While some CDV strain variations and related differences in lesion patterns exist (Summers et al., 1984a), in the vast majority of cases of spontaneous and experimental distemper with so-called demyelinating strains, such as R252 (McCullough et al., 1974) and A75/17 CDV (Summers et al., 1979), the virus causes multifocal lesions in the gray as well as in the white matter of the CNS (Summers et al., 1995). The demyelinating lesions are not only responsible for severe neurological signs but are also thought to be a model for human demyelinating conditions, such as multiple sclerosis (Appel et al., 1981; Dal Canto and Rabinowitz, 1982). It has even been proposed by several groups that, on the basis of epidemiological and molecular studies, CDV could be the cause of multiple sclerosis (Krakowka and Koestner, 1978; Cook et al., 1979, 1980, 1986, 1995; Cook and Dowling, 1980; Hughes et al., 1980; Appel et al., 1981; Madden et al., 1981; Rohowosky et al., 1995; De Keyser et al., 2001; Gilden, 2002). Therefore, the pathogenesis of demyelination in distemper has been investigated closely in recent years. In the following, we will focus on the current knowledge of the pathogenesis of demyelination in canine distemper.

Pathogenesis studies have to consider an acute and a chronic stage in the development of CDV-induced demyelination. The initial lesions occur around 3 weeks after infection and evolve during a period of massive virus-induced immunosuppression (Vandevelde et al., 1982a). Depending on the degree and speed of immune recovery, animals may either become moribund quickly or recover after developing a mild or subclinical illness. An intermediate group of animals recovers slowly or partially, and tends to develop a chronic or relapsing disease with progression of the demyelinating lesions as a result of immunopathological reactions (Vandevelde et al., 1981, 1982b).

\section{The acute stage of CDV-induced demyelination}

The initial myelin lesions develop during a period of severe immunosuppression and are not inflammatory (Vandevelde et al., 1982a) (Fig. 1). Several immunocytochemical studies and recent in situ hybridization work in spontaneous and experimental distemper have clearly shown that demyelination coincides with replication of CDV in the glial cells of the white matter (Vandevelde et al., 1985b; Zurbriggen et al., 1993). Spatiotemporal studies leave no doubt that the initial white matter lesions are associated with viral activity and that their development is highly predictable (Summers et al., 1979; Higgins et al., 1982; Vandevelde et al., 1985b) (Fig. 2). The most obvious explanation for demyelination would be infection of oligodendrocytes, the myelin-producing cells.

Therefore, research has focused on evidence of CDV (mRNA, viral antigen) in oligodendrocytes. At the light microscope level, it has been shown that the majority of infected cells are astrocytes (Mutinelli et al., 1989). Most electron microscope studies agree that oligodendroglial infection is very rare in distemper (Wisniewski et al.,

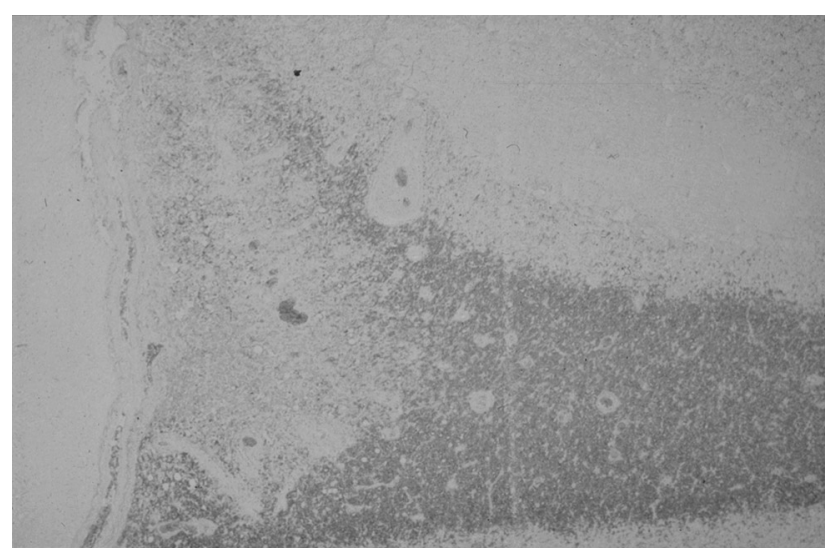

Fig. 1. Acute demyelinated region in the cerebellum after natural canine distemper virus infection. Immunohistochemistry for myelin basic protein showing oligodendrocytes, the myelin-producing cells. 


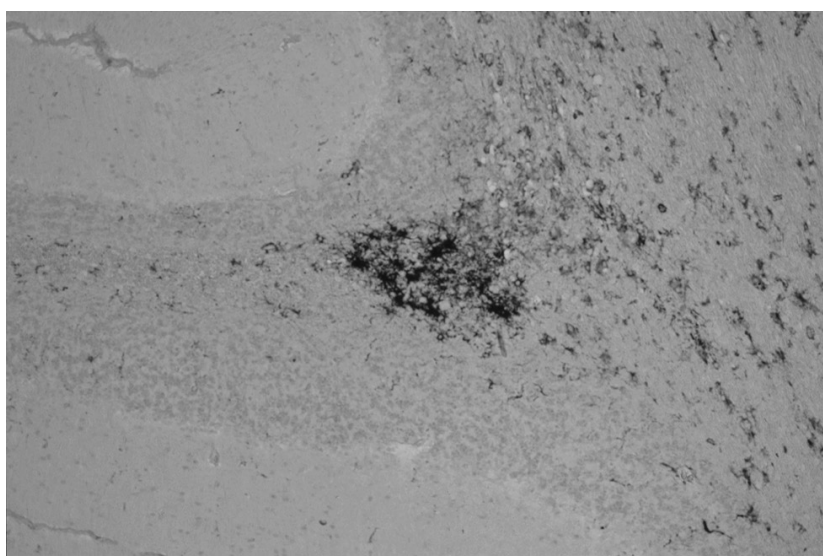

Fig. 2. Canine distemper virus in the white matter of the cerebellum demonstrated by in situ hybridization using a probe specific for mRNA coding for the P-protein. Acute phase of the disease.

1972; Raine, 1976; Higgins et al., 1982; Summers and Appel, 1987; Blakemore et al., 1989; Glaus et al., 1990). Very few oligodendrocytes containing CDV antigen were found at the light microscope level. However, approximately $8 \%$ of the oligodendrocytes at the edge of lesions contained CDV mRNA (Zurbriggen et al., 1998). This restricted infection of oligodendrocytes was found earlier in dog brain cell cultures (DBCC) (Zurbriggen et al., 1993), in which virulent CDV causes a slowly spreading non-cytolytic infection. CDV proteins or viral nucleocapsids were found only very rarely in oligodendrocytes in culture, in contrast to astrocytes and microglial cells, which easily support CDV infection (Vandevelde et al., 1985a; Zurbriggen et al., 1986, 1987). We conclude from these studies that CDV causes a restricted infection of the oligodendrocytes, which is possibly responsible for the phenomenon of demyelination. Why the production of viral protein does not take place in these cells remains to be elucidated.

Between 20 and 30 days after infection, cultured oligodendrocytes, which grow on top of a layer of astrocytes in mixed DBCC, start to degenerate and disappear, although the supporting culture remains a continuous cell sheet (Zurbriggen et al., 1987). Ultrastructural studies revealed microvacuolation and loss of organelles in such oligodendrocytes (Glaus et al., 1990). The morphological changes are preceded by metabolic dysfunction of these cells, because the activity of cerebroside sulfotransferase-an oligodendrocyte-specific enzyme-decreased markedly soon after infection (Glaus et al., 1990) and myelin transcription is strongly decreased in infected DBCC (Graber et al., 1995). It was shown in vivo that CDV infection led to massive down-regulation of myelin gene transcription, with complete loss of in situ hybridization for proteolipid protein in oligodendrocytes within demyelinating lesions (Zurbriggen et al., 1998). Morphological changes of oligodendrocytes were also described in the demyelinating lesions in vivo using elec- tron microscopy (Summers and Appel, 1987; Blakemore et al., 1989). The fate of the oligodendrocytes remains unclear, and there is no solid evidence that these cells undergo necrosis or apoptosis in CDV infection, either in vivo or in vitro (Schobesberger et al., 1999).

There is little doubt that a change in these cells is at the root of the demyelinating process, but its mechanism is not yet understood. It is possible that viral transcription taking place in these cells interferes with the specialized functions necessary to maintain myelin membranes. The possibility that these cells are affected as a result of virus-induced changes in other cell types cannot be excluded. However, a series of experiments could not confirm this hypothesis. Supernatants derived from CDV-infected DBCC did not induce oligodendroglial lesions in recipient dog or mouse brain cell cultures (Zurbriggen et al., 1987). We were unable to find evidence of toxic factors, such as tumour necrosis factor $\alpha$ and reactive oxygen radicals, in the supernatants of CDV-infected DBCC (Brügger et al., 1992). Cocultivation of infected DBCC with mouse brain cell cultures, which are refractory to CDV, did not damage the mouse oligodendrocytes (unpublished results, C. Griot and A. Zurbriggen). Likewise, the mouse brain cells (which remained uninfected in these cocultures) did not provide protection for the canine oligodendrocytes (unpublished results, C. Griot and A. Zurbriggen).

In summary, acute CDV infection of the white matter results in metabolic oligodendroglial changes, which lead to demyelination. Whether the change in the oligodendrocytes is the direct result of the restricted CDV infection mentioned above remains to be shown.

The contribution of the immune response to early lesion development is not clear. While an effective antiviral neutralizing immune response is lacking in the acute phase of distemper, anti-CDV IgM antibodies occur within the first 2 weeks of infection (Barben et al., 1999). Despite severe immunosuppression and lack of perivascular cuffing, numerous $\mathrm{CD}^{+}$cells are found in acute demyelinating lesions and are diffusely distributed in the brain parenchyma, roughly correlating with areas of viral infection. In the cerebrospinal fluid (CSF) of such animals, high titers of interleukin 8 are found (Tipold et al., 1999). It has been suggested that initial macrophage/microglial cell activation, which occurs in distemper (Alldinger et al., 1996), may trigger invasion of T cells into the CNS (Tipold et al., 1999). Antiviral cytotoxic immune reactions have been shown only in the later stage of the disease (Appel et al., 1982). It is uncertain, therefore, whether the invading cells have any effect on infected cells.

\section{The chronic stage of distemper: immunopathological complications}

Coinciding with the recovery of the immune system, perivascular cuffing with lymphocytes, plasma cells and 
monocytes occurs in the initial virus-induced brain lesions (Vandevelde et al., 1981). The inflammatory reaction in the demyelinating lesions can lead to progression of the tissue damage (Wisniewski et al., 1972; Vandevelde et al., 1982b). There is often necrosis of the tissue in such lesions, even though a significant number of oligodendrocytes is still present in chronic, completely demyelinated lesions (Schobesberger et al., 2002). Thus, the chronic stage of the disease is mainly characterized by immunopathological complications.

It has been known for many years that anti-myelin antibodies in serum occur in distemper (Krakowka et al., 1973). We found such antibodies also in the CSF of dogs with distemper, and that these antibodies are produced locally in the inflammatory brain lesions (Vandevelde et al., 1986). A cell-mediated response against myelin basic protein was found in four of 11 dogs experimentally infected with CDV (Cerruti Sola et al., 1983). However, neither anti-myelin antibodies nor cell-mediated antimyelin reactions correlate with the course of the disease. In addition, distemper has no resemblance to experimental autoimmune encephalitis (Summers et al., 1984b).

The initial intrathecal immune response in distemper during the immunosuppressive stage of the disease consists in diffuse invasion of $\mathrm{CD}^{+} \mathrm{T}$ cells (Tipold et al., 1999). During immune recovery, a mature immune reaction develops by perivascular infiltration of $\mathrm{CD}^{+}$cells and subsequent recruitment of large numbers of plasma cells and elevated antibody synthesis (Vandevelde et al., 1981, 1986; Tipold et al., 1999; Wunschmann et al., 1999). The titers of CDV-neutralizing antibodies in the CSF often exceed those in the serum (Bollo et al., 1986). Binding studies show that antibodies are made against all proteins of CDV (Johnson et al., 1988). The occurrence of anti-CDV antibodies in the CSF coincided with clearance of $\mathrm{CDV}$ and $\mathrm{CDV}$-containing cells from the inflammatory lesions (Bollo et al., 1986; Baumgärtner et al., 1989; Alldinger et al., 1993b).

We found that antiviral antibodies bound to the surface of CDV-infected cells interacted with the Fc receptors of neighbouring macrophages by way of their Fc portions (Bürge et al., 1989; Griot et al., 1989a, b). This interaction resulted in a respiratory burst in macrophages, with release of reactive oxygen species (ROS). We could also show that stimulation of macrophages by way of their Fc receptors or other means, including antiviral antibody-virus immune complexes, led to selective destruction of oligodendrocytes in their vicinity (Griot et al., 1990; Griot-Wenk et al., 1991; Botteron et al., 1992). These experiments showed how the humoral antiviral immune response could lead to destruction of oligodendrocytes as innocent bystander cells (Griot et al., 1990). Obviously, several products secreted by stimulated macrophages/microglia, including ROS, can be made responsible for damage to the oligodendrocyte/myelin compartment. ROS produced chemically using the xanthine/xanthine oxidase system, selectively damaged cultured oligodendrocytes when added to the culture supernatant (Griot et al., 1990); these cells are rich in transferrin and therefore contain a considerable iron load (Griot and Vandevelde, 1988), rendering them particularly vulnerable to ROS attacks. The procoagulant activity of macrophages was markedly enhanced after CDV infection (Brügger et al., 1992), which may enhance the destructive potential of macrophages and provide further support for the hypothesis that bystander demyelination occurs in chronic distemper. The experimental conditions in the antibody experiments in vitro closely mimic the situation in vivo, in which CDV-infected glial cells in the white matter are in close contact with macrophages/microglia and antiviral antibody-producing cells. Therefore, it is not unreasonable to conclude that a bystander mechanism associated with the antiviral immune response is responsible for the progression of demyelinating lesions in the chronic stage of CDV infection (Griot et al., 1990).

\section{Further progression of the disease: virus persistence}

The antiviral immune response should be beneficial to the host insofar as CDV is removed from the tissue (Bollo et al., 1986). However, our studies also showed that CDV can persist in white matter areas outside the inflammatory demyelinating lesions (Bollo et al., 1986). It appears, therefore, that a chronic progressive disease develops if the intrathecal immune response keeps lagging behind viral replication. Thus, viral persistence must be the key to the pathogenesis of the chronic lesions. We found that persistent CDV spreads in a noncytolytic manner by way of cell processes with very limited budding and release of infectious virus (Zurbriggen et al., 1995) compared with attenuated viruses. In addition, $\mathrm{CDV}$ is capable of producing restricted infection in neurons without expressing viral protein (Müller et al., 1995). Others have found restricted expression of surface proteins in the CNS (Alldinger et al., 1993a). Persistence of CDV appears to be related to mechanism(s) preventing recognition of the virus by immunocompetent cells. As sequencing studies have shown differences between virulent and attenuated CDV at the level of the NP, M, F and $\mathrm{H}$ genes (Stettler et al., 1997; Cherpillod et al., 1999), it will be difficult to relate persistence to single molecular determinants.

\section{Prevention of CDV infection}

Much has been learned about the development of the CNS lesions in canine distemper. Some of these findings may provide a basis for the development of therapeutic strategies, in particular at the immunomodulatory level and/or in reactivating oligodendrocytes from a progeni- 
tor pool, even in chronically demyelinated lesions (Schobesberger et al., 2002). However, while modification of the detrimental inflammatory response may become feasible, the basic problem remains the presence of the virus in the CNS.

Effective antiviral therapies against morbilliviruses are not available yet. Therefore, the most important veterinary intervention remains prevention. Whereas vaccines against CDV have been available for a long time and have greatly reduced the incidence of the disease, avianized strains offer inadequate protection against the nervous form of CDV (Tipold et al., 1996), and other vaccine strains may cause postvaccinal encephalitis (Hartley, 1974; Cornwell et al., 1988). However, it is most important to have significant information on disease pathogenesis before any therapeutic or preventive approach is attempted.

It might be impossible to eradicate CDV because of its global distribution and the wide variety of susceptible wildlife species, which include marine and freshwater seals, African cats and many others. Therefore, on the basis of solid information on the pathogenesis of CDV, the development of new preventive approaches, such as the use of recombinant DNA vaccines, has been undertaken. Recently, a DNA vaccine derived from virulent CDV sequences was developed (Cherpillod et al., 2000). Plasmids were constructed containing the nucleocapsid, fusion protein and attachment protein genes of virulent CDV. Preliminary studies have shown that this vaccine induces both humoral and cellular immune response against CDV antigens, and protects from virulent CDV challenge (Cherpillod et al., 2000). Furthermore, the immune response in puppies has been evaluated after priming vaccination with CDV DNA followed by conventional vaccination. The combination of the two vaccines induced a strong humoral immune response (unpublished results, C. Griot and A. Zurbriggen).

\section{Conclusions}

Novel morbilliviruses have emerged in recent years, either as newly identified viruses or as viruses crossing species barriers. The observation of morbilliviruses causing re-emerging and newly emerging diseases is consistent with the fact that RNA viruses have a considerable potential to mutate, and therefore can easily adapt to new hosts within a short period (Domingo and Holland, 1994; Cleaveland et al., 2001). CDV has been in the carnivore population for many years and molecular epidemiological evidence suggests that the virus has not changed in the past.

Canine distemper is a well-studied member of the Morbillivirus genus, and investigation of the pathogenesis of CDV infection might provide information as to the pathogenesis of related viruses within the same family. New morbillivirus-like viruses have shown zoonotic potential and therefore are of relevance for public health. There is a need for better preventive and diagnostic tools in the future because the vectors carrying some of these viruses are also present in wildlife and may hardly ever be eradicated (Daszak et al., 2000).

Thus, morbilliviruses continue to surprise us. With new molecular techniques at hand and our present knowledge of the disease mechanism of prototype members of the Paramyxoviridae, we are in a better position to rapidly identify, understand and design preventive or even therapeutic measures against them.

\section{Acknowledgments}

We were supported by the Swiss National Science Foundation (grants 32-49506.96 and 31-56686.99), the Swiss Multiple Sclerosis Society and the Swiss Federal Veterinary Office. The authors wish to thank Rosmarie Fatzer and Marlies Schlatter for carefully reviewing the manuscript.

\section{References}

Alldinger S, Baumgärtner W and Örvell C (1993a). Restricted expression of viral surface proteins in canine distemper encephalitis. Acta Neuropathologica (Berlin) 85: 635-645.

Alldinger S, Baumgärtner W, van Moll P and Örvell C (1993b). In vivo and in vitro expression of canine distemper viral proteins in dogs and non-domestic carnivores. Archives of Virology 132: 421-428.

Alldinger S, Wunschmann A, Baumgärtner W, Voss C and Kremmer E (1996). Up-regulation of major histocompatibility complex class II antigen expression in the central nervous system of dogs with spontaneous canine distemper virus encephalitis. Acta Neuropathologica (Berlin) 92 : 273-280.

Appel MJ (1969). Pathogenesis of canine distemper. American Journal of Veterinary Research 30: 1167-1182.

Appel MJ, Glickman LT, Raine CS and Tourtellotte WW (1981). Canine viruses and multiple sclerosis. Neurology 31: 944-949.

Appel MJ, Shek WR and Summers BA (1982). Lymphocytemediated immune cytotoxicity in dogs infected with virulent canine distemper virus. Infection and Immunity 37: 592-600

Appel MJG, Yates RA and Foley GL (1994). Canine distemper epizootic in lions, tigers and leopards in North America. Journal of Veterinary Diagnostic Investigation 6: 277-288.

Barben G, Stettler M, Jaggy A, Vandevelde M and Zurbriggen A (1999). Detection of IgM antibodies against the nucleocapsid protein of canine distemper virus in dog sera using a dot-blot-assay. Journal of Veterinary Medicine A $\mathbf{4 6}$ : $115-121$.

Barclay AJ and Paton DJ (2000). Hendra (equine morbillivirus). Veterinary Journal 160: 169-176.

Barrett T (1999). Morbillivirus infections, with special emphasis on morbilliviruses of carnivores. Veterinary Microbiology 69: $3-13$

Barrett T, Visser IKG, Mamaev L, Goatley L, Van Bressem MF and Osterhaus ADME (1993). Dolphin and porpoise morbilliviruses are genetically distinct from phocine distemper virus. Virology 193: 1010-1012. 
Baumgärtner W, Örvell C and Reinacher M (1989). Naturally occurring canine distemper virus encephalitis: distribution and expression of viral polypeptides in nervous tissues. Acta Neuropathologica 78: 504-512.

Blakemore WF, Summers BA and Appel MG (1989). Evidence of oligodendrocyte infection and degeneration in canine distemper encephalomyelitis. Acta Neuropathologica 77: $550-553$.

Bollo E, Zurbriggen A, Vandevelde M and Fankhauser R (1986). Canine distemper virus clearance in chronic inflammatory demyelination. Acta Neuropathologica 72: 69-73.

Bolt G, Jensen TD, Gottschalck E, Arctander P, Appel MJ, Buckland R and Blixenkrone-Moller M (1997). Genetic diversity of the attachment $(\mathrm{H})$ protein gene of current field isolates of canine distemper virus. Journal of General Virology 78: 367-372.

Botteron C, Zurbriggen A, Griot C and Vandevelde M (1992). Canine distemper virus-immune complexes induce bystander degeneration of oligodendrocytes. Acta Neuropathologica 83: 402-407.

Brown C (1997). Emerging diseases-what veterinarians need to know. Journal of Veterinary Diagnostic Investigation 9 113-117.

Brügger M, Jungi TW, Zurbriggen A and Vandevelde M (1992). Canine distemper virus increases procoagulant activity of macrophages. Virology 190: 616-623.

Bürge T, Griot C, Vandevelde M and Peterhans E (1989). Antiviral antibodies stimulate production of reactive oxygen species in cultured canine brain cells infected with canine distemper virus. Journal of Virology 63: 2790-2797.

Bush M, Montali RJ, Brownstein D, James AE Jr and Appel MJ (1976). Vaccine-induced canine distemper in a lesser panda. Journal of the American Veterinary Medical Association 169: 959-960.

Carpenter JW, Appel MJ, Erickson RC and Novilla MN (1976). Fatal vaccine-induced canine distemper virus infection in black-footed ferrets. Journal of the American Veterinary Medical Association 169: 961-964.

Cerruti Sola S, Kristensen F, Vandevelde M, Bichsel P and Kihm U (1983). Lymphocyte responsiveness to lectin and myelin antigens in canine distemper infection in relation to the development of demyelinating lesions. Journal of Neuroimmunology 4: 77-90.

Cherpillod P, Beck K, Zurbriggen A and Wittek R (1999). Sequence analysis and expression of the attachment and fusion proteins of canine distemper virus wild-type strain A75/17. Journal of Virology 73: 2263-2269.

Cherpillod P, Tipold A, Griot-Wenk M, Cardozo C, Schmid I, Fatzer R, Schobesberger M, Zurbriggen R, Bruckner L, Roch F, Vandevelde M, Wittek R and Zurbriggen A (2000). DNA encoding nucleocapsid and surface proteins of wild type canine distemper virus protects its natural host against distemper. Vaccine 18: 2927-2936.

Chua KB, Goh KJ, Wong KT, Kamarulzaman A, Tan PS, Ksiazek TG, Zaki SR, Paul G, Lam SK and Tan CT (1999). Fatal encephalitis due to Nipah virus among pig-farmers in Malaysia. Lancet 354: 1256-1259.

Chua KB, Bellini WJ, Rota PA, Harcourt BH, Tamin A, Lam SK, Ksiazek TG, Rollin PE, Zaki SR, Sheih WJ, Goldsmith CS, Gubler DJ, Roehrig JT, Eaton B, Gould AR, Olson J, Field $\mathrm{H}$, Daniels P, Ling AE, Peters CJ, Anderson LJ and Mahy WJ (2000). Nipah virus: a recently emergent deadly paramyxovirus. Science 288: 1432-1435.

Chua KB, Koh CL, Hooi PS, Wee KF, Khong JH, Chua BH, Chan YP, Lim ME and Lam SK (2002). Isolation of Nipah virus from Malaysian island flying-foxes. Microbes and Infection 4: 145-151.
Cleaveland S, Appel MG, Chalmers WS, Chillingworth C, Kaare $M$ and Dye C (2000). Serological and demographic evidence for domestic dogs as a source of canine distemper virus infection for Serengeti wildlife. Veterinary Microbiology 72: 217-227.

Cleaveland S, Laurenson MK and Taylor LH (2001). Diseases of humans and their domestic mammals: pathogen characteristics, host range and the risk of emergence. Philosophical Transactions of the Royal Society of London Series B, Biological Sciences 356: 991-999.

Cook SD, Dowling PC and Russell WC (1979). Neutralizing antibodies to canine distemper and measles virus in multiple sclerosis. Journal of the Neurological Sciences 41: 61-70.

Cook SD and Dowling PC (1980). Multiple sclerosis and viruses: an overview. Neurology 30: 80-91.

Cook SD, Gudmundsson G, Benedikz J and Dowling PC (1980). Multiple sclerosis and distemper in Iceland 1966-1978. Acta Neurologica Scandinavica 61: 244-251.

Cook SD, Blumberg B and Dowling PC (1986). Potential role of paramyxoviruses in multiple sclerosis. Neurologic Clinics 4: 303-319.

Cook SD, Rohowsky-Kochan C, Bansil S and Dowling PC (1995). Evidence for multiple sclerosis as an infectious disease. Acta Neurologica Scandinavica Supplement 161 $34-42$.

Cornwell HJ, Thompson H, McCandlish IA, Macartney L and Nash AS (1988). Encephalitis in dogs associated with a batch of canine distemper (Rockborn) vaccine. Veterinary Record 122: 54-59.

Dal Canto MC and Rabinowitz SG (1982). Experimental models of virus-induced demyelination of the central nervous system. Annals of Neurology 11: 109-127.

Daszak P, Cunningham AA and Hyatt AD (2000). Emerging infectious diseases of wildlife-threats to biodiversity and human health. Science 287: 443-449.

Deem SL, Spelman, LH, Yates RA and Montali RJ (2000). Canine distemper in terrestrial carnivores: a review. Journal of Zoo and Wildlife Medicine 31: 441-451.

De Keyser J, Wilczak N, Walter JH and Zurbriggen A (2001). Disappearance of beta2-adrenergic receptors on astrocytes in canine distemper encephalitis: possible implications for the pathogenesis of multiple sclerosis. Neuroreport 12: 191-194.

Domingo E and Holland JJ (1994). Mutation rates and rapid evolution of RNA viruses. In: Morse SS (editor). The Evolutionary Biology of Viruses. New York: Raven Press, pp. 151-184.

Duignan PJ, Saliki JT, St Aubin DJ, Early G, Sadove S, House JA, Kovacs K and Geraci JR (1995). Epizootiology of morbillivirus infection in North American harbor seals (Phoca vitulina) and gray seals (Halichoerus grypus). Journal of Wildlife Diseases 31: 491-501.

Ek-Kommonen C, Sihvonen L, Pekkanen K, Rikula U and Nuotio L (1997). Outbreak of canine distemper in vaccinated dogs in Finland. Veterinary Record 141: 380-383.

Gemma T, Watari T, Akiyama K, Miyashita N, Shin YS, Iwatsuki K, Kai C and Mikami T (1996). Epidemiological observations on recent outbreaks of canine distemper in Tokyo area. Journal of Veterinary Medical Science $\mathbf{5 8}$ $547-550$.

Gilden DH (2002). A search for virus in multiple sclerosis. Hybridoma and Hybridomics 21: 93-97.

Glaus T, Griot C, Richard A, Althaus U, Herschkowitz N and Vandevelde M (1990). Ultrastructural and biochemical findings in brain cell cultures infected with canine distemper virus. Acta Neuropathologica (Berlin) 80: 59-67.

Graber H, Müller C, Vandevelde M and Zurbriggen A (1995). 
Restricted infection with canine distemper virus leads to down-regulation of myelin gene transcription in cultured oligodendrocytes. Acta Neuropathologica (Berlin) 90 312-318.

Griot C and Vandevelde M (1988). Transferrin, carbonic anhydrase $\mathrm{C}$ and ferritin in dissociated murine brain cell cultures. Journal of Neuroimmunology 18: 333-340.

Griot C, Bürge T, Vandevelde M and Peterhans E (1989a). Antibody-induced generation of reactive oxygen radicals by brain macrophages in canine distemper encephalitis: a mechanism for bystander demyelination. Acta Neuropathologica 78: 396-403.

Griot C, Bürge T, Vandevelde M and Peterhans E (1989b). Bystander demyelination through antibody induced macrophage activation in canine distemper virus infection. Schweizer Archiv für Neurologie, Neurochirurgie und Psychiatrie 140: 39-41.

Griot C, Vandevelde M, Richard A, Peterhans E and Stocker R (1990). Selective degeneration of oligodendrocytes mediated by reactive oxygen species. Free Radical Research Communications 11: 181-193.

Griot-Wenk M, Griot C, Pfister H and Vandevelde M (1991). Antibody-dependent cellular cytotoxicity in anti-myelin antibody-induced oligodendrocyte damage in vitro. Journal of Neuroimmunology 33: 145-155.

Harcourt BH, Tamin A, Ksiazek TG, Rollin PE, Anderson LJ, Bellini WJ and Rota PA (2000). Molecular characterization of Nipah virus, a newly emergent paramyxovirus. Virology 271: 334-349.

Harder TC, Kenter M, Appel MJG, Roelke-Parker ME, Barrett T and Osterhaus ADME (1995). Phylogenetic evidence of canine distemper virus in Serengeti's lions. Vaccine $\mathbf{1 3}$ $521-523$

Hartley WJ. (1974). A post-vaccinal inclusion body encephalitis in dogs. Veterinary Pathology 11: 301-312.

Higgins RJ, Krakowka SG, Metzler A and Koestner A (1982). Primary demyelination in experimental canine distemper virus induced encephalomyelitis in gnotobiotic dogs. Sequential immunologic and morphologic findings. Acta Neuropathologica 58: 1-8.

Hooper PT and Williamson MM (2000). Hendra and Nipah virus infections. Emerging Infectious Diseases 16: 597-603.

Hughes RA, Russell WC, Froude JR and Jarrett RJ (1980). Pet ownership, distemper antibodies and multiple sclerosis Journal of the Neurological Sciences 47: 429-432.

Ikeda Y, Nakamura K, Miyazawa T, Chen MC, Kuo TF, Lin JA, Mikami T, Kai C and Takahashi E (2001). Seroprevalence of canine distemper virus in cats. Clinical and Diagnostic Laboratory Immunology 8: 641-644.

Jensen T, van de Bildt M, Dietz HH, Andersen TH, Hammer AS, Kuiken T, Osterhaus A (2002). Another phocine distemper outbreak in Europe. Science 297: 209.

Iwatsuki K, Miyashita N, Yoshida E, Gemma T, Shin YS, Mori T, Hirayama N, Kai C and Mikami T (1997). Molecular and phylogenetic analyses of the haemagglutinin $(\mathrm{H})$ proteins of field isolates of canine distemper virus from naturally infected dogs. Journal of General Virology 78: 373-380.

Johnson GC, Fenner WR and Krakowka S (1988). Production of immunoglobulin $\mathrm{G}$ and increased antiviral antibody in cerebrospinal fluid of dogs with delayed-onset canine distemper viral encephalitis. Journal of Neuroimmunology 17: 237-251.

Johnson R, Glickman LT, Emerick TJ and Patronek GJ (1995). Canine distemper infection in pet dogs: I. Surveillance in Indiana during a suspected outbreak. Journal of the American Animal Hospital Association 31: 223-229.

Kennedy S, Kuiken T, Jepson PD, Deaville R, Forsyth M, Barrett T, van de Bildt MWG, Osterhaus ADME, Eybatov T, Duck C, Kydyrmanov A, Mitrofanov I and Wilson S (2000). Mass die-off of Caspian seals caused by canine distemper virus. Emerging Infectious Diseases 6: 637-639.

Krakowka S (1982). Mechanisms of in vitro immunosuppression in canine distemper virus infection. Journal of Clinical and Laboratory Immunology 8: 187-196.

Krakowka S and Koestner A (1978). Canine distemper virus and multiple sclerosis. Lancet 1: 1127-1128.

Krakowka S, McCullough B, Koestner A and Olsen R (1973). Myelin-specific auto-antibodies associated with central nervous system demyelination in canine distemper virus infection. Infection and Immunity 8: 819-827.

Krakowka S, Higgins RJ and Koestner A (1980). Canine distemper virus: review of structural and functional modulations in lymphoid tissues. American Journal of Veterinary Research 41: 284-292.

Lam SK and Chua KB (2002). Nipah virus encephalitis outbreak in Malaysia. Clinical Infectious Diseases 34: 48-51.

Leisewitz AL, Carter A, van Vuuren M and van Blerk L (2001). Canine distemper infections, with special reference to South Africa, with a review of the literature. Journal of the South African Veterinary Association 72: 127-136.

Mackenzie JS, Chua KB, Daniels PW, Eaton BT, Field HE, Hall RA, Pin K, Johansen CA, Kirkland PD, Lam SK, McMinn P, Nisbet DJ, Paru R, Pyke AT, Ritchie SA, Siba P, Smith DW, Smith GA, van den Hurk AF, Wang LF and Williams DT (2001). Emerging viral diseases of Southeast Asia and the Western Pacific. Emerging Infectious Diseases 7: 497-504.

Madden DL, Wallen WC, Houff SA, Shekarchi IC, Leinikki PO, Castellano GA and Sever JL (1981). Measles and canine distemper antibody. Presence in sera from patients with multiple sclerosis and matched control subjects. Archives of Neurology 38: 13-15.

Mayo MA (2002). Virus taxonomy-Houston 2002. Archives of Virology 147: 1071-1076.

McCullough B, Krakowka S and Koestner A (1974). Experimental canine distemper virus-induced demyelination. Laboratory Investigation 31: 216-222.

Morell V (1996). New virus variant killed Serengeti cats. Science 271: 596.

Müller C, Fatzer R, Beck K, Vandevelde M and Zurbriggen A (1995). Studies on canine distemper virus persistence in the nervous system. Acta Neuropathologica (Berlin) 89: 438-445.

Murray PK, Selleck P, Hooper P, Hyatt A, Gould A, Gleeson L, Westbury H, Hiley L, Selvey L, Rodwell B and Ketterer P (1995). A morbillivirus that caused fatal disease in horses and humans. Science 268: 94-97.

Murray PK, Eaton B, Hooper P, Wang L, Williamson M and Young P (1998). Flying foxes, horses and humans: a zoonosis caused by a new member of the Paramyxoviridae. In: Scheld WM, Armstrong $\mathrm{O}$ and Hughes JM (editors). Emerging Infections 1. Washington, DC: ASM Press, pp. 43-58

Mutinelli F, Vandevelde M, Griot C and Richard A (1989). Astrocytic infection in canine distemper virus-induced demyelination. Acta Neuropathologica (Berlin) 77: 333-335.

Olson JG, Rupprecht C, Rollin PE, An US, Niezgoda M, Clemins T, Walston J and Ksiazek TG (2002). Antibodies to Nipahlike virus in bats (Pteropus lylei), Cambodia. Emerging Infectious Diseases 8: 987-988.

Osterhaus ADME (2001). Catastrophes after crossing species barriers. Philosophical Transactions of the Royal Society of London Series B Biological Sciences 356: 791-793.

Osterhaus ADME and Vedder EJ (1988). Identification of virus causing recent seal deaths. Nature 335: 20.

Osterhaus ADME, Groen J, De Vries P, Uytdehaag FGCM, Klingeborn B and Zarnke R (1988). Canine distemper virus in seals [letter]. Nature 335: 403-404. 
Osterhaus ADME, Groen J, UytdeHaag FGCM, Visser IKG, van de Bildt MWG, Bergman A and Klingeborn B (1989). Distemper virus in Baikal seals. Nature 338: 209-210.

O'Sullivan JD, Allworth AM, Paterson DL, Snow TM, Boots R, Gleeson LJ, Gould AR, Hyatt AD and Bradfield J (1997). Fatal encephalitis due to novel paramyxovirus transmitted from horses. Lancet 349: 93-95.

Raine CS (1976). On the development of CNS lesions in natural canine distemper encephalomyelitis. Journal of the Neurological Sciences 30: 13-28.

Roelke-Parker ME, Munson L, Packer C, Kock R, Cleaveland S, Carpenter M, O'Brien SJ, Pospischil A, Hofmann-Lehmann R, Lutz H, Mwamengele GLM, Mgasa MN, Machange GA, Summers BA and Appel MJG (1996). A canine distemper virus epidemic in Serengeti lions (Panthera leo). Nature 379: 441-445.

Rogers RJJ, Douglas IC, Baldock FC, Glanville RJ, Seppanen KT, Gleeson LJ, Selleck PN and Dunn KJ (1996). Investigation of a second focus of equine morbillivirus infection in coastal Queensland. Australian Veterinary Journal 74: 243-244.

Rohowsky-Kochan C, Dowling PC and Cook SD (1995). Canine distemper virus-specific antibodies in multiple sclerosis. Neurology 45: 1554-1560.

Schobesberger M, Zurbriggen A, Summerfield A, Vandevelde M and Griot C (1999). Oligodendroglial degeneration in distemper: apoptosis or necrosis? Acta Neuropathologica (Berlin) 97: 179-187.

Schobesberger M, Zurbriggen A, Doherr MG, Weissenböck H, Vandevelde M, Lassmann H and Griot C (2002). Demyelination precedes oligodendrocyte loss in canine distemper virus-induced encephalitis. Acta Neuropathologica (Berlin) 103: 11-19.

Stettler M and Zurbriggen A (1995). Nucleotide and deduced amino acid sequences of the nucleocapsid protein of the virulent A75/17-CDV strain of canine distemper virus. Veterinary Microbiology 44: 211-217.

Stettler M, Beck K, Wagner A, Vandevelde M and Zurbriggen A (1997). Determinants of persistence in canine distemper viruses. Veterinary Microbiology 57: 83-89.

Summers BA and Appel MJ (1987). Demyelination in canine distemper encephalomyelitis: an ultrastructural analysis. Journal of Neurocytology 16: 871-881.

Summers BA, Greisen HA and Appel MJ (1979). Early events in canine distemper demyelinating encephalomyelitis. Acta Neuropathologica (Berlin) 46: 1-10.

Summers BA, Greisen HA and Appel MJ (1984a). Canine distemper encephalomyelitis: variation with virus strain. Journal of Comparative Pathology 94: 65-75.

Summers BA, Greisen HA and Appel MJ (1984b). Canine distemper and experimental allergic encephalomyelitis in the dog: comparative patterns of demyelination. Journal of Comparative Pathology 94: 575-589.

Summers BA, Cummings JF and deLahunta A (1995). Canine distemper. In: Veterinary Neuropathology. St Louis: Mosby, pp. 102-110.

Tipold A, Jaggy A, Zurbriggen A and Vandevelde M (1996). Neurological signs in canine distemper encephalomyelitis-a clinical study. European Journal of Companion Animal Practice 6: 33-38.

Tipold A, Moore P, Zurbriggen A, Burgener I, Barben G and Vandevelde M (1999). Early T-cell response in the central nervous system in canine distemper virus infection. Acta Neuropathologica (Berlin) 97: 45-56.
Van de Bildt MWG, Kuiken T, Visee AM, Lema S, Fitzjohn TR and Osterhaus ADME (2002). Distemper outbreak and its effect on African wild dog conservation. Emerging Infectious Diseases 8: 211-213.

Vandevelde M and Zurbriggen A (1995). The neurobiology of canine distemper virus infection. Veterinary Microbiology 44: 271-280

Vandevelde M, Fankhauser R, Kristensen F and Kristensen B (1981). Immunoglobulins in demyelinating lesions in canine distemper encephalitis. An immunohistological study. Acta Neuropathologica (Berlin) 54: 31-41.

Vandevelde M, Higgins RJ, Kristensen B, Kristensen F, Steck AJ and Kihm U (1982a). Demyelination in experimental canine distemper virus infection: immunological, pathologic, and immunohistological studies. Acta Neuropathologica (Berlin) 56: 285-293.

Vandevelde M, Kristensen F, Kristensen B, Steck AJ and Kihm U (1982b). Immunological and pathological findings in demyelinating encephalitis associated with canine distemper virus infection. Acta Neuropathologica (Berlin) 56: 1-8.

Vandevelde M, Zurbriggen A, Dumas M and Palmer D (1985a). Canine distemper virus does not infect oligodendrocytes in vitro. Journal of the Neurological Sciences 69: 133-137.

Vandevelde M, Zurbriggen A, Higgins RJ and Palmer D (1985b). Spread and distribution of viral antigen in nervous canine distemper. Acta Neuropathologica (Berlin) 67: 211-218

Vandevelde M, Zurbriggen A, Steck A and Bichsel P (1986). Studies on the intrathecal humoral immune response in canine distemper encephalitis. Journal of Neuroimmunology 11: $41-51$.

Wang LF and Eaton BT (2001). Emerging paramyxoviruses. Infectious Disease Review 3: 52-69.

Wang LF, Yu M, Hansson E, Pritchard LI, Shiell B, Michalski WP and Eaton BT (2000). The exceptionally large genome of Hendra virus: support for creation of a new genus within the family Paramyxoviridae. Journal of Virology 74: 9972-9979.

Wisniewski H, Raine CS and Kay WJ (1972). Observations on viral demyelinating encephalomyelitis. Canine distemper. Laboratory Investigation 26: 589-599.

Wunschmann A, Alldinger S, Kremmer E and Baumgärtner W (1999). Identification of $\mathrm{CD}^{+}$and $\mathrm{CD}^{+} \mathrm{T}$ cell subsets and $\mathrm{B}$ cells in the brain of dogs with spontaneous acute, subacute-, and chronic-demyelinating distemper encephalitis. Veterinary Immunology and Immunopathology $\mathbf{6 7}$ 101-116.

Zurbriggen A, Vandevelde M and Dumas M (1986). Secondary degeneration of oligodendrocytes in canine distemper virus infection in vitro. Laboratory Investigation 54: 424-431.

Zurbriggen A, Vandevelde M, Dumas M, Griot C and Bollo E (1987). Oligodendroglial pathology in canine distemper virus infection in vitro. Acta Neuropathologica (Berlin) 74: 366-373.

Zurbriggen A, Yamawaki M and Vandevelde M (1993). Restricted canine distemper virus infection of oligodendrocytes. Laboratory Investigation 68: 277-284.

Zurbriggen A, Graber H, Wagner A and Vandevelde M (1995). Canine distemper persistence in the nervous system is associated with non-cytolytic virus spread. Journal of Virology 69: 1678-1686.

Zurbriggen A, Schmid I, Graber HU and Vandevelde M (1998). Oligodendroglial pathology in canine distemper. Acta Neuropathologica (Berlin) 95: 71-77. 